\title{
Reviving the Demographic Study of the Amish
}

Corey Colyer ${ }^{1}$

Associate Professor of Sociology

Department of Sociology

West Virginia University

Cory Anderson ${ }^{1}$

Visiting Assistant Professor of Sociology and Geography

Department of Society and Environment

Truman State University

Rachel Stein

Associate Professor of Sociology

Department of Sociology

West Virginia University

\author{
Joseph Donnermeyer \\ Professor Emeritus of Rural Sociology \\ School of Env. and Natural Resources \\ The Ohio State University
}

Samson Wasao

African Institute for Development Policy, Nairobi, Kenya /

Independent Researcher, Columbus, $\mathrm{OH}$

\begin{abstract}
The Amish exhibit distinctive demographic patterns, notably high fertility. While scholars have studied Amish population dynamics for more than a half century, recent research in this area is limited. We believe the time is ripe to reverse this trend. This article reviews data collection methods, points to a variety of accessible sources of new data, presents some preliminary results from the analysis of one such source (the McKune dataset for Holmes County, Ohio), introduces the research agenda and work of the newly formed Amish Population Research Group, and reviews past demographic findings to situate our agenda. An invitation is extended to demographers, social scientists, health researchers, and others to enter into collaborations with APRG.
\end{abstract}

\section{Keywords}

Amish Population Research Group; Fertility; Population studies; Holmes County, Ohio; Association of Religion Data Archives; Benjamin Allen McKune (1980-2014); Unobtrusive measures; Microdata; Elmer Lewis Smith; Amish settlement directories; Amish genealogies

\section{Acknowledgements}

We are grateful to the Association of Religion Data Archive at Pennsylvania State University for preparing, releasing, and working with us on the McKune dataset. Further, the section "What Do We Know?” was drafted while Anderson was under the support of a Kreider fellowship at the Young Center for Anabaptist and Pietist Studies. 


\section{Introduction}

A health scholar seeking assistance in finding population statistics on the Amish contacted our newly-formed Amish Population Research Group, writing:

I am a nurse researcher who works with a local Amish population to perform research about aging in the Amish community. I have not been able to find any statistical information about the numbers or characteristics of aging Amish and was hoping you might be able to help me. I did try to use the ${ }^{2}$ website but was unsuccessful in finding any concrete information about Old Order Amish specifically, either at a national or state level in regards to persons over the age of 55. (Email sent to Corey Colyer, July 9, 2016)

The health scholar sought descriptive statistics to summarize aging patterns among the Amish. Unfortunately, such summary statistics do not (yet) exist. While an impressive number of population studies examining the Amish and plain Anabaptist communities were published in the last decade, we still lack accessible and reliable metrics on key demographic indicators such as fertility, mortality, age structure, sex ratios, and so forth. The current state of Amish demographic studies reflects a paucity of useable micro data. ${ }^{3}$ Current work instead tracks settlement patterns (emergence, growth, decline, and extinction) and aggregate population estimates (total population, population doubling rates, etc.).

Amish communities are generally inaccessible to researchers and their members are resistant to questionnaires, recorded interviews, and other conventions for obtaining valid demographic measures. To contend with these obstacles, demographers resort to so-called unobtrusive measures (Webb, Campbell, Schwartz, and Sechrest 1966), deriving population parameter estimates from administrative records and other social artifacts.

In this article, we trace the history of data collection for Amish studies, including a peek at the McKune dataset, and then introduce the work of the Amish Population Research Group. The Amish Population Research Group was formed in May of 2015, in part, to collectively identify ways to leverage newly found demographic data sources. We outline the potential and frustrations associated with using these new resources. In the remainder of this paper, we synthesize Amish demographic findings to date.

\section{Obtaining Useful Micro Data}

The Amish are notoriously difficult to tap for data for several reasons, including their long-rooted religious practice of separation from the world, the amount of time it takes to build trust and rapport, the resilience the social system has to finding a natural and acceptable role in the system for the researcher, and the cultural inappropriateness of normal institutional methods for collecting data (Adkins, 2011; Enninger \& Wandt 1983; McKusick, Hostetler, and Egeland 1964; Savells and Foster 1987; Yost, et al. 2005). Elmer Lewis Smith-the first researcher to 
present an extensive demographic study of the Amish-faced much travail in his nevertheless path blazing work:

In June 1954, an attempt was made to use a questionnaire as part of this study. Forty forms were sent to selected Amish persons and forty to selected non-Amish persons in a given geographical area. Although the instructions seemed clear and simple, and a statement of the reason for the need for the information was included, along with a self-addressed and stamped envelope, none of these was returned by the Amish, and only three were returned by non-Amish, with two of the later group sending back blank forms. Needless to say, this method was abandoned. (Smith 1956, 23)

Smith also had trouble getting anyone (Amish, or non-Amish) living in the Lancaster community to "go on the record" in one-on-one interviews. "One interviewee would not answer the questions when there were any Amish people in his store, as he said, 'Talking about them might be bad for business, and most of my business comes from them'” (Smith 1956, 24). Not that a whole lot has changed since then. More recently, Hurst and McConnell (2010) worked with similar reserve among the Holmes County, Ohio, Amish.

When the members of a population group resist the standard tools for gathering demographic data, researchers must become creative and locate indirect measures, such as social artifacts, for analysis. The most successful survey and structured interview studies related to demography com from health studies, including genetics. Such studies success gather data since they tap into the Amish desire to help others and because of indirect returns in the form of medical assistance (e.g. finding treatments for rare genetic disorders) (Armer and Radina 2006; Tell 2012). While health studies and demography have much overlap-especially in the study of morbidity - the ways a demography study are helpful and provide returns to the Amish are less easily articulated. Hence, demography data collection efforts have at times required creativity.

Once again, we point to Smith as a model for the contemporary scholar. Smith discovered that Pennsylvania marriage license applications contained exceptionally rich data: "Marriage license application records provide many means for sociological inquiry and measurement including studies of residential stability and mobility, occupational changes between father and son, divorce and remarriage, age at marriage and family size” (Smith 1956, p. 22). These applications included fields for race, occupation, birthplace, residence, date of birth, number of previous marriages, and reason for dissolution of previous marriages. The form included similar fields concerning the applicant's parentage.

Smith discovered that these records allowed him to estimate population parameters for age, sex, birth spacing, and so forth. The challenge was in restricting the set of marriage licenses to only Amish. He accomplished this by first compiling a surname census of the Lancaster community (primarily by driving the county with a knowledgeable informant and recording the surnames of Amish households) and selecting marriage licenses filed by applicants bearing one of the top 14 surnames. He further restricted his dataset to those marriages performed by Amish bishops (as identified by a Mennonite yearbook). 
Smith's data collection efforts were clearly extraordinary! And the demand for such creativity has not abated since. A similar and more recent effort was Sharon Hewner's census of the Conewango Valley, NY, Amish settlement (Hewner 1997; 1998). Initial attempts to locate Amish elders as community gatekeepers failed, so Hewner started mapping households. She used the local public school district's census of the student-age population in their area, which included students attending the Amish parochial schools. She rounded out her demographic data collection with (1) a key informant who added information to the school record-derived household entries, (2) an Amish woman's diary that recorded births, deaths, and migrations, and (3) cemetery records of an Amish individual. From her census, Hewner calculated fertility rates, death rates, migration rates, and a time-series of population pyramids.

Due to the cumbersomeness of data scavenger hunts like those of Smith and Hewner, most demographers have turned to large Amish settlements with extensive family genealogical records. In the 1960s, geneticists Harold Cross and Victor McKusick developed a dataset of all Holmes County Amish, living and deceased. The result was a 1965 Amish Holmes County directory. While the Holmes County Amish produced directories since 1940, the Cross and McKusick directory was vastly expanded, including birthdates for all household members, marriage dates, and occupation / employer. Amish cooperation was evidently offered, given both the benefits of having skillfully developed directories available and research progress in Amishspecific genetic disorders. Demographic results were published in Social Biology in 1970 (Cross \& McKusick 1970) and a collection of demographic papers by numerous authors in an edited volume later that decade (McKusick 1978).

A similar effort was underway in Elkhart / LaGrange Counties, IN; Geauga County, OH; and Lancaster County, PA, and involved the efforts of three Temple University sociologists: Julia Ericksen, John Hostetler, and Eugene Ericksen, and also Gertrude Enders Huntington (1977). The overview culminated in a Population Studies article (Ericksen, et al. 1979).

Thereafter, cross-settlement studies withered, that is, until the Anabaptist Genealogy Database emerged. In the late 1990s, Johns Hopkins researchers advanced their genetic research by compiling an extensive genealogical database of Amish and Mennonite ancestry, starting in Lancaster County, PA, but eventually extending to places across the country (Agarwala, Biesecker, Hopkins, Francomano, and Schäffer 1998; Agarwala, Biesecker, and Schäffer 2003; Lee, Pollin, O'Connell, Agarwala, and Schäffer 2010).

While this genetic database has provided material for many studies, it lacks some variables of interest to demographers and social scientists, including occupations, names, household location, baptism codes, and some dates of vital events. Outside of early demography studies and genetic research, what few authors who have attempted a demographic study of the Amish have with few exceptions (1) focused on one settlement of Amish, and (2) relied on the more recent directory editions. Table 1 tracks the history of data sources. This has been the most convenient formula, but is limited in its settlement-specific setup. 


\section{Table 1: Data for Major Amish Population Studies}

\begin{tabular}{|c|c|c|}
\hline Study & Data type & Data source \\
\hline \multirow{2}{*}{ Smith (1960) } & & Fisher book \\
\hline & Public records: & Lancaster Co., PA, vital statistics records \\
\hline Espenshade (1971) & Genealogies: & Fisher book \\
\hline $\begin{array}{l}\text { Cross \& McKusick } \\
\text { (1970) }\end{array}$ & Directories: & Holmes County, OH \\
\hline Resseguie (1974) & Field work: & $\begin{array}{l}\text { Colette Wiffler's Midwestern Amish interview data of 7,500 } \\
\text { pregnancies }\end{array}$ \\
\hline $\begin{array}{l}\text { Markle \& Pasco } \\
\text { (1977) }\end{array}$ & Directories: & Elkhart-LaGrange, IN \\
\hline $\begin{array}{l}\text { Ericksen, Ericksen, } \\
\text { Hostetler, Huntin- } \\
\text { gton }(1977,1979)\end{array}$ & $\begin{array}{l}\text { Genealogies: } \\
\text { Directories: } \\
\text { Field work: }\end{array}$ & $\begin{array}{l}\text { Fisher book } \\
\text { Elkhart-LaGrange / Holmes / Geauga Co., OH / Lancaster Co. } \\
\text { Survey of } 258 \text { Amish in Lancaster Co., PA }\end{array}$ \\
\hline Miller (1980) & Genealogies: & Fisher book \\
\hline $\begin{array}{l}\text { Hamman, et al. } \\
\text { (1981) }\end{array}$ & $\begin{array}{l}\text { Directories: } \\
\text { Public records: }\end{array}$ & $\begin{array}{l}\text { Elkhart-LaGrange / Holmes / Lancaster Co. } \\
\text { Death certificates }\end{array}$ \\
\hline $\begin{array}{l}\text { Hurd (1985a, 1985b, } \\
\text { 1997) }\end{array}$ & $\begin{array}{l}\text { Genealogies: } \\
\text { Field work: }\end{array}$ & $\begin{array}{l}\text { Genealogies } \\
\text { Key informants }\end{array}$ \\
\hline Acheson (1994) & Directories: & Geauga Co. \\
\hline $\begin{array}{l}\text { Dorsten }(1994,1999 a, \\
\text { 1999b) }\end{array}$ & $\begin{array}{l}\text { Genealogies: } \\
\text { Directories: }\end{array}$ & $\begin{array}{l}\text { Lancaster Co. Family Register } \\
\text { Lancaster Co. }\end{array}$ \\
\hline Wood, et al. (1994) & Directories: & Central Pennsylvania \\
\hline $\begin{array}{l}\text { Wasao \& Donner- } \\
\text { meyer (1996) }\end{array}$ & Directories: & Holmes Co. \\
\hline \multirow[t]{2}{*}{$\begin{array}{l}\text { Hewner (1997, } \\
\text { 1998,2001) }\end{array}$} & Public records: & $\begin{array}{l}\text { Informants; informant diary and cemetery records; surveys; } \\
\text { interviews }\end{array}$ \\
\hline & Field work: & School district student census \\
\hline Mitchell, et al. (2001) & $\begin{array}{l}\text { Genealogies: } \\
\text { Field work: }\end{array}$ & $\begin{array}{l}\text { Fisher book } \\
\text { "Field work" to fill in missing entries }\end{array}$ \\
\hline Greksa $(2002,2003)$ & Directories: & Geauga Co. \\
\hline $\begin{array}{l}\text { Agarwala, Biesecker, } \\
\text { et al. }(1998,2003)\end{array}$ & Genealogies: & $\begin{array}{l}\text { Fisher book; Amish \& Amish-Mennonite Genealogies (1986); } \\
\text { James Hostetler genealogy data; others }\end{array}$ \\
\hline $\begin{array}{l}\text { Donnermeyer \& } \\
\text { Cooksey }(2004,2013)\end{array}$ & Directories: & Holmes Co., OH; Iowa \\
\hline
\end{tabular}




\section{Today’s Amish Directories}

At present, Amish demographic information is more bountiful than ever. The development of large settlement directories spawned an ever-growing series of directories among smaller and newer settlements. Amish directories are now so common that the vast majority of Amish individuals are represented in one (if not two!) of these books, with the notable exception of most Swartzentruber and Stutzman-Troyer Amish. The Heritage Historical Library in Aylmer, Ontario, has an extensive collection which Joseph Donnermeyer has used to plot settlement growth and expansion. To date, we have identified right at 50 Amish directories published since 2011 - this not including several settlements with directories not updated since 2011 and individual settlement or inter-settlement directories with different waves of data, e.g. several daughter settlements have their own directories and are also in a "mother" settlement's directory.

Amish directories organize population information by households within church districts, of which there may be as few as 29 (Frazeysburg, OH) or as many as around 11,000 (Lancaster Co., and daughter settlements). The directory itself may represent a state (e.g. the Wisconsin directory), a settlement (e.g. the Daviess County, IN, directory), a tradition (e.g. the Nebraska Amish directory), a shared migration pattern (e.g. the daughter settlements of Dover, DE, directory), an affiliation (e.g. the New Order directory), or a combination of these (e.g. the Ohio directory for Holmes County and in-state daughter settlements). Directories solve many of the data access characterizing so many sequestered, high fertility populations of interest to demographers. Figure 1 is an entry from the 2015 Ohio Amish Directory, Holmes Co. edition.

\section{Figure 1: Extract from the 2015 Holmes County Directory}

\begin{tabular}{|c|c|c|}
\hline $\mathbf{T}, \mathbf{A}$ & e A Jr & Pine Acres Woodcraft \\
\hline 11 & Rd NW Sugarcreek O & $(330)$ \\
\hline b.8/28/1933 & Abe M \& Lovina N (B & $\mathrm{m} .10 / 7 / 1965$ to \\
\hline Esther $\mathbf{S}$ & b.1/15/1942 to Jonas & diann $(\mathrm{T}-)$ \\
\hline Schlabach & & \\
\hline Dusane Andrew & 09/02/1966 D Virginia R Troyer & Leesburg OH 45135 \\
\hline Diana Sue & 03/02/1971 B Edwin R Schlabach & Sugarcreek OH 44681 \\
\hline Dennis Edward & 01/02/1975 D Cynthia Hostetler & Sugarcreek OH 44681 \\
\hline Daniel Lee & $\begin{array}{c}\text { 01/08/1976 B Laurie E Beachy } \\
44681\end{array}$ & Sugarcreek $\mathrm{OH}$ \\
\hline Dean Robert & $\begin{array}{c}\text { 11/23/1979 B Ada J Stutzman } \\
\text { OH } 44681\end{array}$ & Rd SW Sugarcreek \\
\hline
\end{tabular}

The record includes the following fields:

- Name (surname, first name, middle initial)

- Occupation or employer (from which occupation may be inferred)

- Address 
- Date of birth

- Parents (names, including mother's maiden name)

- Date of marriage

- Wife (first name, middle initial, maiden name)

- Wife's date of birth

- Wife's parents (names, including mother's maiden name)

- Spouse date of death, if deceased

- Children

o Name

o Date of birth

o Address (if not in household)

o Date of death, if deceased

o Code for current status in the church

In addition, district title pages list the bishop, ministers, and deacon. Other directories may also include fields for in-migration date and origin, district code for children if living away from home, and other variables.

From these five to ten lines of text, we can calculate a vast number of metrics concerning Abe T. and his family. For instance, Abe was 81 years old on the first day of 2015, while Esther was 72 . They were 32 (Abe) and 23 (Esther) respectively when they married (yielding an 8 year difference). Their first child (Duane) was born 11 months after their marriage date, which was in early autumn. The spacing between children averaged 40 months (or slightly more than 3 years between children). Esther was 37 years old when her youngest child was born, which is old enough to be considered a high risk pregnancy. They had five children, all married, although two of them left the Amish.

While these individual calculations may be interesting, they are not analytically useful on their own. They become analytically useful when aggregated into larger units of analysis (e.g. average number of children in the district, number of high risk pregnancies in the settlement, or average spacing between births). All of these measures can serve as independent variables in regression models (logistic regression, survival analysis, or even simple least squares equations) which, when properly specified, can help us fine tune our theoretical explanations and better understand those mechanisms that drive Amish growth, decline, and transition.

Clearly, the content of Amish directories is analytically useful, but the information is time consuming to extract. Most of these documents are available only as hard copy printed books. To conduct the sorts of analysis described above, the information must be converted into machine readable form. The daunting amount of work involved has no doubt deterred researchers from undergoing anything but directory samples, but this is now changing. 


\section{The McKune Dataset}

In early 2015, we learned of an ambitious attempt by a Pennsylvania State University doctoral student in sociology to create a comprehensive microdata census of the Holmes County, $\mathrm{OH}$, settlement using high quality image scanning, optical character recognition (OCR), personal ancestry files, and text parsing software. Tragically, Benjamin Allen McKune (1980-2014) passed away from an undiagnosed heart condition before completing the project. At the time of his death, McKune had built an enormous dataset. He had digitized copies of the 1965, 1973, 1981, 1988, 1996, 2000, 2005, and 2010 Holmes County directories and converted the images into machine-readable text using high powered optical character recognition software. A text conversion algorithm allowed him to parse the information into Personal Ancestry Files (commonly used in genealogical research) where duplicate records (e.g., where the same person appears in multiple directories) were consolidated. Finally, he generated a microdata array of 46,710 records. ${ }^{4}$

McKune was a research associate with the Association of Religion Data Archives (ARDA). After he passed, his family allowed ARDA to make the data from his unfinished dissertation available to the broader research community. Unfortunately, the dataset has not been fully cleaned. A combination of OCR artifacts and inadvertent bugs in the PHP code makes the data unreliable for analysis. Age calculations are particularly vulnerable to these sorts of errors (Table 2).

\section{Table 2: Errors in the Data-Negative Age at Death}

\begin{tabular}{lll} 
Birthdate & Deathdate & Age at Death \\
\hline $02 / 01 / 1989$ & $08 / 11 / 1984$ & -4 \\
$08 / 29 / 1978$ & $07 / 30 / 1919$ & -59 \\
$11 / 21 / 1988$ & $05 / 31 / 1986$ & -2 \\
$05 / 01 / 1940$ & $05 / 07 / 1910$ & -29 \\
$06 / 14 / 1974$ & $04 / 10 / 1969$ & -5 \\
$12 / 20 / 1981$ & $11 / 07 / 1978$ & -3 \\
$02 / 06 / 1941$ & $04 / 26 / 1920$ & -20 \\
$01 / 28 / 1966$ & $09 / 10 / 1964$ & -1 \\
$04 / 15 / 1984$ & $04 / 15 / 1964$ & -20 \\
$09 / 05 / 1963$ & $09 / 05 / 1959$ & -4
\end{tabular}

Without a thorough cleaning of the data, we cannot be confident in findings drawn on the dataset. However, we can use these data to illustrate the broader value of microdata for demographic analysis. 


\section{Preliminary Analysis of the McKune Holmes County Data}

With the last micro-data-based demography studies being conducted around the turn of the millennium, it is time to update the findings, if for no other reason than the Amish population has nearly doubled since the last studies of the 1990s occurred (Donnermeyer 2015). The McKune dataset is a starting place. It incorporates data through 2010 and is sufficiently robust to allow an estimate of total population by year. Figure 2 plots the total population of the Holmes County Settlement between 1965 and 2010.

\section{Figure 2: Population Growth 1965 to 2010 Estimated from the McKune Data}

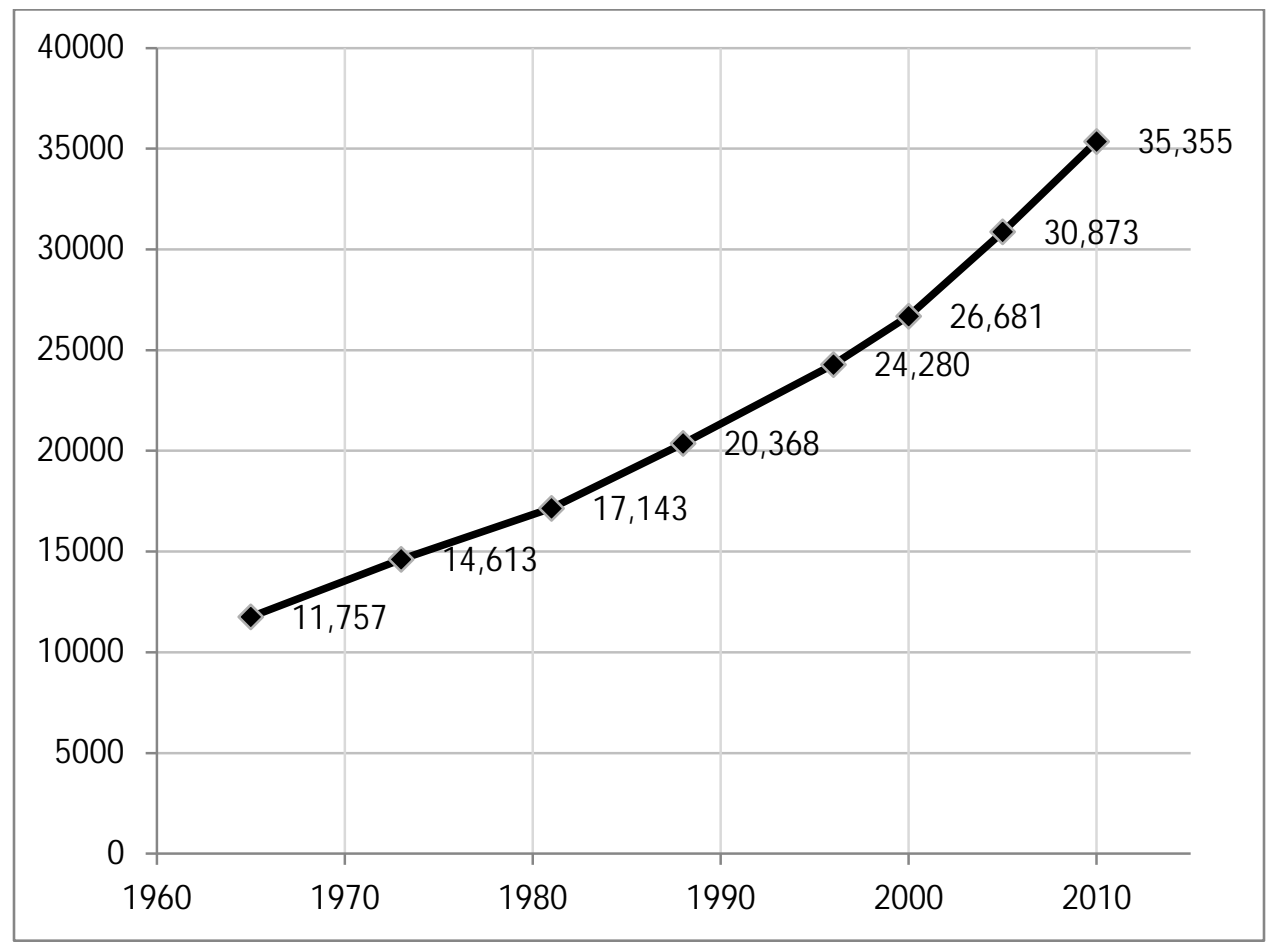

The population grew by approximately 200\% in this 45 year period (between 1965 and 2010). Thus, over the full run of available data, the doubling time is approximately 30 years, which is much longer than traditional estimates of 20 to 25 years. However, the trend line is loglinear. Population growth accelerates. By 1981, our estimated doubling time approaches 20 years and is consistent with Donnermeyer's formula.

Other measurements from the McKune data suggest stunning demographic stability. Consider Table 3. Note the striking stability in age and gender structure. Gender ratio remains almost evenly split across the 45-year period. Likewise, the median age remains steady. This suggests that, consistent with Hurst and McConnell's (2010) findings, the Amish families of Holmes County retain their young. The one discernible pattern in the data is decreasing family size starting with the 2000 directory. The median number of children remained consistent for 30 years. Then, in 2000, the family size declined. 
Table 3: Percent Female, Median Age, and Number of Children, 1965 to 2010 Holmes County Settlement

\begin{tabular}{llll} 
Year & Percent Female & Median Age & Median Number of Children \\
\hline 1965 & $49.4 \%$ & 23 & 6 \\
1973 & $49.4 \%$ & 22 & 6 \\
1981 & $49.3 \%$ & 23 & 6 \\
1988 & $49.6 \%$ & 23 & 6 \\
1996 & $49.3 \%$ & 23 & 6 \\
2000 & $49.5 \%$ & 22 & 5 \\
2005 & $49.5 \%$ & 22 & 5 \\
2010 & $49.2 \%$ & 23 & 4
\end{tabular}

The directory data also allow us to track the incidence of infant mortality. The directories are not a great source of mortality information for the population as a whole because adult deaths are not consistently captured. Child deaths, however, are captured with regularity in the directories, allowing us to examine infant mortality patterns. Figure 3 presents a distribution frequency of age at death from the McKune dataset.

Figure 3: Frequency Distribution of Age at Death, 1965 to 2010, Estimated from the McKune Data

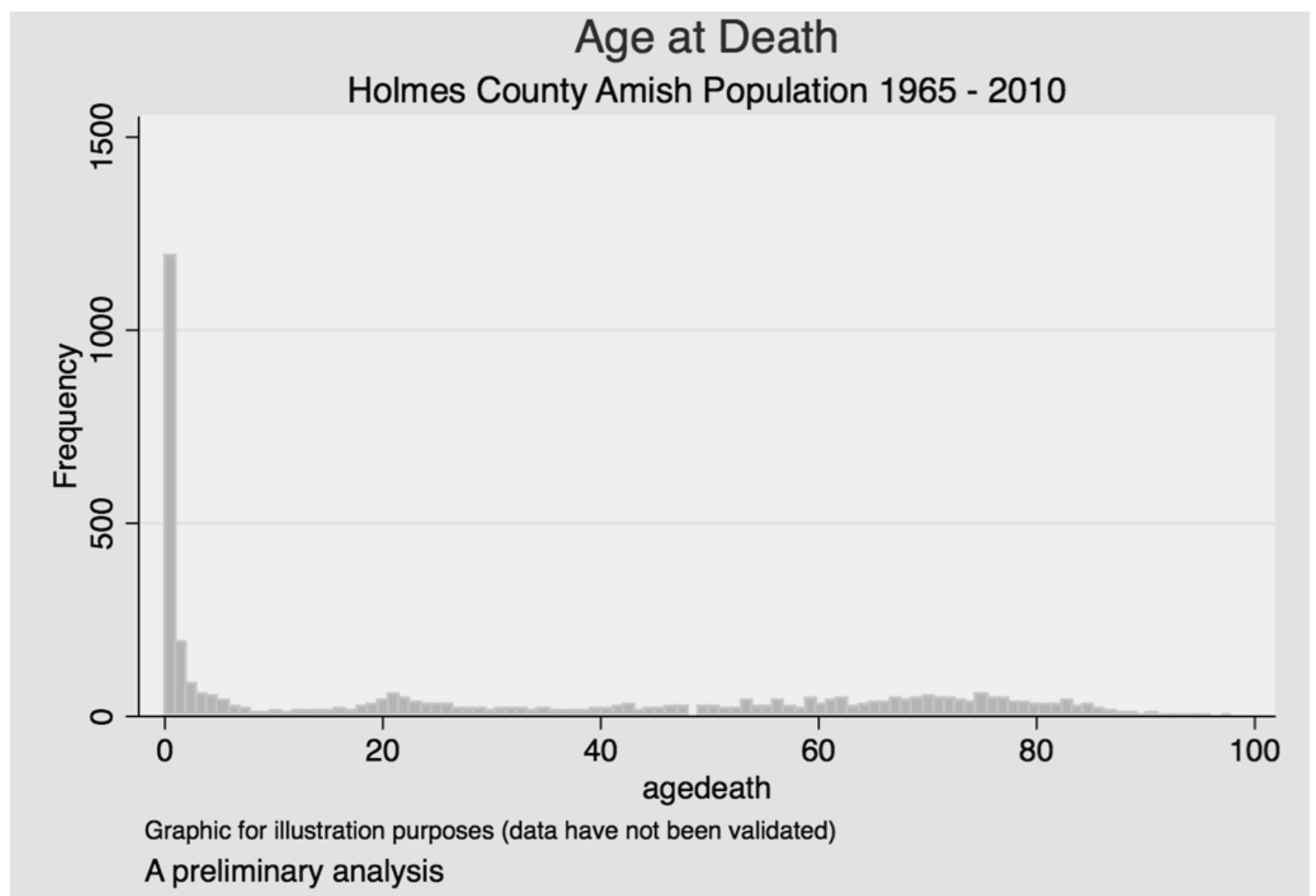


We note the exponentially high incidence of infant deaths. Again, the mortality data extracted from directories are not complete. For a full mortality estimate, these data will need to be augmented with other official records. But these measurements are sufficient to determine if the incidence of infant mortality is increasing, decreasing, or staying the same. Table 4 presents the distribution of infant mortality (defined as a death involving a person 1 year of age or younger) by decade.

\section{Table 4: Infant Mortality by Decade}

\begin{tabular}{ll} 
Decade & $\begin{array}{l}\text { Percentage of Deaths Recorded in } \\
\text { the Directory Involving an Infant }\end{array}$ \\
\hline $1950-1959$ & $39.2 \%$ \\
$1960-1969$ & $33.9 \%$ \\
$1970-1979$ & $32.2 \%$ \\
$1980-1989$ & $28.8 \%$ \\
$1990-1999$ & $26.1 \%$ \\
$2000-2010$ & $21.1 \%$
\end{tabular}

We can see that the incidence has been roughly cut in half. This may well contribute to the acceleration of the doubling rate observed in Figure 2 above. It opens several pertinent questions for social scientists and public health scholars. Why has the incidence of infant mortality decreased so precipitously? Does this rate match, exceed, or fall behind the rate for the population in Ohio more broadly? What lessons can we derive from these measurements?

\section{The Current State of Amish Demography}

As mentioned in the opening, demographic studies of Amish populations tend to focus on settlements as the primary unit of analysis. Scholars seeking population estimates on the Amish turn to two primary sources: (1) 2010 U.S. Religion Census (Grammich, et al. 2012) provides estimates of the Amish population at the county level; and (2) Annual Amish Population Profiles prepared and distributed by the Young Center for Anabaptist and Pietist Studies at Elizabethtown (PA) College (Burdge 2016).

First, Ohio State University rural sociologist Joseph Donnermeyer prepared the county level Amish population estimates for the 2010 U.S. Religion Census and used his data to estimate patterns of variation in the size of Amish settlements in North America (Donnermeyer, Anderson, and Cooksey 2013; Donnermeyer \& Cooksey 2010). His methods are meticulously detailed in both articles, as well as in an appendix of the 2010 U.S. Religion Census book. Donnermeyer draws from a list of all known Amish ministers printed annually in Raber's Almanac, correspondent reports published in several Amish newspapers (Die Botschaft, The Budget, and The Diary), family counts from state and regional settlement directories, and miscellaneous information published in regional newsletters. Most of these sources provide 
counts of various entities (settlements, families, births, migrations, etc.). Second, the Young Center researchers maintain a variety of tables estimating population change over varying periods. Estimates of the Amish population are released annually. ${ }^{7}$ Many of the sources Donnermeyer uses are also used by the Young Center, although differences in techniques produce disparities in estimates (Donnermeyer \& Anderson 2015).

However interesting, these population and settlement tallies fail to address questions and offer data that inform theory-building in demography, and hence fall somewhat outside of demography and under a more general "population studies” umbrella. They provide, for example, no detailed information on patterns of nativity and mortality. Theoretical explanations for the rapid rate of Amish growth tend to focus on the ethnic community's birthrate, longevity, exclusive within-group marriage patterns, and low rate of youth apostasy (Dorsten 1999; Dorsten, Hotchkiss, and King 1996; Hostetler 1963; Kollmorgen 1943; Schwieder \& Schwieder 1975; Smith 1960). And yet, without measurements on such key indicators as lifespan, birth spacing, and gender structure, such theoretical explanations rest on assumptions.

Two of us (Stein and Colyer) recently interviewed an Old Order Amish bishop who suggested that families in his district are having fewer children. When asked why this might be, he said, "Well, we listen to our doctors," implying that some of the women are now using birth control and other family planning technologies. If this is true (and applicable beyond this bishop's district), it has far reaching implications for our understanding of the social system's adaptation to stresses. Representative micro data from different Amish communities would allow us to examine birth patterns (spacing between births, decrease of pregnancies at certain ages, etc). Fortunately, such microdata will soon exist in database form.

\section{Research Potentials: The Amish Population Research Group}

The Amish Population Research Group was established in May 2015 in response to ARDA's release of the McKune dataset. Given the great potential of such a dataset, five sociologists interested in the demographic study of the Amish met to develop a research agenda. The founders included Cory Anderson (Truman State University), Corey Colyer (West Virginia University), Joe Donnermeyer (Ohio State University), Rachel Stein (West Virginia University), and Samson Wasao (African Institute for Development Policy, Nairobi, Kenya). The founders brought a diversity of skills to the group, including demography theory, quantitative methodology, and Amish scholarship. Different guest researchers have also been present at each meeting.

Shortly after developing a research agenda, the group discovered the aforementioned errors in the database. Text recognition errors in dates pose serious threats to the validity of demographic analysis. The group has secured copies of McKune's source materials as well as hard copies of source documents and we are working on correcting the errors. This slow work is ongoing. 
Simultaneously, the group was exploring ways to develop a comprehensive database of the Amish population across North America. For over a decade, Donnermeyer had been collecting Amish directories and Elizabeth Cooksey—a prior co-author-had been hiring student workers to manually enter data. The process was slow. However, Anderson was able to use the scholarship service program at Truman State University ${ }^{8}$ to recruit talented students whose cumulative contributions to manual data entry approximated 80 work hours a week during the 2016-17 school year.

Even with the large number of man-hours logged to data entry, the amount of data to be entered is simply overwhelming. Take the 2015 Lancaster County Amish directory for instance. The directory consists of 612 8”x11.5” pages with narrow margins. Each page is packed from margin-to-margin with text, as thick as phone book pages. And yet, it was the seemingly insurmountable task of entering data from the very large Amish settlements that pushed us to develop an alternative to manual data entry. Taking a cue from McKune, Anderson had the major Amish directories scanned at a high resolution and ran a sophisticated OCR on the pages. The results were not perfect, but they were very, very good! We then began work on developing a computer program that could read these OCR-ready files and sort the data into fields. The program can now read six directory layouts, including Lancaster. The program continues to be refined, with the goal of being able to read one of any number of directory formats, sorting the data into appropriate fields and including auto-checks for probable errors. Between the quality OCR and sophisticated code, we anticipate being able to not only read a window of current directories, but also past and future directories with ease.

The code applies best to directories that are nicely laid out with common fonts. However, many directories are too rough to scan, OCR-text recognize, and run the code on. Take the Wisconsin directory, for instance. In all likelihood, the compiler probably typed up the entries on a typewriter and then had the pages photocopied and bound by an outside printer. The directory is too fraught with unusual variations in data presentation, violations of the margins, and messy typesetting to use the program on. Such directories can only be manually entered. However, with the bulk of major settlements and regions producing clean directories-Lancaster, Holmes, Geauga, Elkhart-LaGrange, Nappanee, Adams, Daviess, Arthur, Missouri, Iowa-Minnesota, Great Plains, Michigan, and New Order-the majority of the work can be automated.

Advantages and disadvantages characterize both manual data entry and code data entry. Both are subject to content errors in the directories themselves (incorrectly reported data and incorrectly entered data), although manual entry provides a greater chance that these errors will be identified and corrected. However, manual entry also provides opportunity for incorrect entry, which may not be fully caught in data cleaning. OCR, on the other hand, may incorrectly read a character that a worker would not have. In either case, data cleaning remains an essential step in preparing the data after it has been entered. Yet, even this process can be partially automated with data verification protocols. 
From the new datasets, we envision replicating old demography studies but (1) updating them to the 2011 to 2017 period (2) using a cross-national frame rather than a single settlement, (3) while employing a census of settlements rather than a sample. From these replicated studies, we will be able to calculate the most common yet precise figures pertaining to birth and infant mortality. We also envision employing this unique dataset to the advancement of broader demographic theories by providing a critical test.

\section{What Do We Know? A Meta-Analysis of Amish Demography Studies}

Our massive database - which currently numbers 41,545 households and pending the entry of a few thousand more with the anticipated release of several 2017 directories - is a plantation awaiting harvest. Yet, before presenting demographic results in forthcoming work, we turn to past research, cataloging existing knowledge so that we may identify what data need updating, what theoretical questions have been raised, and where theoretical gaps exist. The following meta-analysis reflects findings by-and-large from individual settlements from around 1900 to 1960, primarily the four largest settlements (Holmes, Lancaster, Elkhart-LaGrange, and Geauga), although several studies analyze data up to 1990 or focus on smaller settlements.

\section{Basic Demographic Dynamics}

Amish have been useful for demographic and genetic studies because they are highly independent of larger society, are endogamous and therefore have a closed gene pool, keep meticulous genealogies, are relatively homogenous in socio-economic indicators, have very low rates of infidelity and divorce, possess relative socio-economic consistency across the population, create permanent conjugal institutions in which nearly all children are born, and have comparatively large families (Cross 1976; Cross \& McKusick 1970; McKusick, et al. 1964). Amish population growth results from high birth rates, low death rates, and high retention rates (Donnermeyer \& Cooksey 2004; Smith 1961), albeit not a high non-Amish conversion rate.

\section{Conversions of Non-Amish}

Conversions of non-Amish to the Amish are far fewer than Amish defectors, although there is certainly no shortage of outsiders entertaining the idea of joining (Anderson 2016). Most Amish do not actively recruit outsiders, though neither are outsiders barred from joining (Smith 1960). Some progressive groups like the New Order Amish are interested in recruiting outsiders, though no major impact is evident (Hostetler 1984). While outsiders may try to join, few successfully overcome the challenge of adjusting to this intensively communal subculture (Friesen \& Friesen 1996). Presently, around 100 Amish members are first generation converts (Scott 2007). Therefore, outside recruitment is only a marginal source of growth. 


\section{Fertility}

The Amish are characterized as a near-natural fertility population (Finn 1995; Greksa 2002; Hewner 1998; Smith 1961), at least up to couples’ mid-30s (Espenshade 1971; Wood et al. 1994). Amish population pyramids diverge sharply from non-Amish neighbors (Enninger \& Wandt 1982; Hewner 1997; Hostetler 1963; Hostetler 1980[1963]), consisting of a full bottom and narrow top, with studies reporting given settlements at a majority under 20 (Cross \& McKusick 1970), 46\% younger than 15 (Greksa 2002), and a 100:110 to 113.5 baptized to unbaptized (pre-adult) ratio (Hostetler 1963; Smith 1960), among others (Hewner 1998). Consequently, population doubling is rapid, occurring every 22.5 to 23 years (Cross and McKusick 1970; Donnermeyer and Cooksey 2004; Greksa 2002) or decennially increasing by $30 \%$ to $47 \%$ across the century (Hostetler 1963). The percent elderly among the Amish remains consistent at around 2\%-3\% (Hewner 1997).

All Amish couples, with the exception of a consistently infertile 3\% (Acheson 1994; Greksa 2002; Smith 1960; Wood et al. 1994), ${ }^{5}$ have children. Completed family live births vary by settlement and twentieth century cohort, but are all high, including 6.33 (Cross and McKusick 1970) , 6.8 (Ericksen, et al. 1979), 7.1 (Kraybill 2001), 7.6 (Dorsten 1994), 7.7 (Greksa 2002), and 7.8 (Acheson 1994). Through most of the past century, fertility increased slightly (Cross and McKusick 1970; Ericksen, et al. 1979; Markle and Pasco 1977), even experiencing an additional increase during the baby boom (Bailey and Collins 2011), though one large, high birth settlement declined by one child by 1967 (Greksa 2002) and another large settlement experienced a slight decrease among late century cohorts (Dorsten 1999).

The household as created through marriages is a critical institution among Amish. In the twentieth century Amish marriages took place around the national average, a little over 21 years of age (Acheson 1994; Cross \& McKusick 1970; Donnermeyer and Cooksey 2004). At midcentury, males tended to marry slightly younger and females slightly older than national averages (Smith 1960), with overall marriage age and the number unmarried by 30 decreasing slightly across the century (Donnermeyer and Cooksey 2004). The evangelically oriented New Order Amish are an exception, with a higher average marriage age and more unmarried by 30 (Donnermeyer and Cooksey 2004). Spousal selection is limited by three factors. Age differences and periodic imbalanced gender ratios limit selection (Smith 1958), but more notably, because of endogamy and a very low non-Amish conversion rate, relatedness restricts marriage. Amish do not marry first cousins (Hurd 1997), and second cousin marriages are generally discouraged, but nevertheless, the net effect of several more distant, but nevertheless, inbred generations create closer relatedness (McKusick et al. 1964) with the total number of inbred couples increasing over time, though the relatedness for all inbred couples has remained stable (Khoury, et al. 1987a). In one Amish sub-faction, the average relatedness of married couples is a little closer than second cousins, which is actually more distant than had all members been randomly paired (Hurd 1985); in a large Pennsylvania settlement, the inbreeding level nearly equates to second cousins (Dorsten, Hotchkiss, and King 1999; Khoury, et al. 1987a). Further, because Amish 
rarely marry across sub-affiliation lines (Hurd 1997) or across settlements, and because they usually stay in the community in which they were born (Cross and McKusick 1970; Donnermeyer and Cooksey 2004), inbreeding is intensified, each major settlement representing a genetic sub-isolate (Cross 1976). High levels of relatedness are positively associated with farming as an occupation, younger age at marriage, higher number of siblings, and having a common last name (Khoury, Cohen, et al. 1987a). At present, relatedness has not become problematic enough to change behavior, and marriages continue. A limited cache of surnames define each settlement (Cross 2003; Smith 1960).

Weddings in eastern Pennsylvania Amish communities tend to occur in late autumn through early winter, though premarital conception-based and remarriage weddings occur throughout the year (Smith 1960). Other Amish settlements have discontinued late autumn weddings, favoring late spring and early autumn (Donnermeyer and Cooksey 2004). Of remarriages, the male has nearly always been married before and the woman a little under half the time. A widower's age is positively related to marrying a widow versus an unmarried woman. Previously unmarried women tend to be much younger than widower husbands (Smith 1960).

Amish fertility is comparable to the Hutterites, both of which are much higher than more assimilated Anabaptist cousin groups (Stevenson, Everson, and Crawford 1989). On average, Amish have had children younger, older, and more frequently than national averages (Smith 1960). ${ }^{6}$ Fatalism (i.e. what is, is God's will) surrounds pregnancy and childbirth (Finn 1995), though varying in intensity across communities. While fecundity varies significantly among couples (Wood, et al. 1994), reproductive span averages 16 years, ending on average at age 37 (Acheson 1994). The mean interval between births is around 20 months (Cross and McKusick 1970). Intervals between first and second birth are shortest, with marriage to first birth the second shortest-over half of all couples have a birth within a year of marriage (Donnermeyer and Cooksey 2004) — then increasingly longer with each child beyond the second and into the latter end of the reproductive span (Dorsten 1999; Ericksen, et al. 1979; Markle and Pasco 1977). All interval lengths have been shorter than national averages (Smith 1960). More recent cohorts have even narrowed the first birth interval (Markle \& Pasco 1977) and have had more children earlier. Recent cohorts in one large settlement have decreased age at last birth, though without decreasing parity (Acheson 1994; Greksa 2002). In general, the church prohibits birth control; in some settlements, couples use it (Jolly 2014; Kraybill 2001), especially those with large families or past perinatal complications (Wenger and Wenger 1998), and in others, even natural methods (e.g. breast feeding, rhythm method) are actively discouraged (Finn 1995).

The Amish reproductive profile has further nuanced attributes. Twinning rates are higher for Amish than non-Amish (Lehman 1994), at 12.2 to 15.3 per 1,000 (Acheson 1994; Cross and McKusick 1970). The vast majority of conceptions occur within marriage, first births occurring within seven or eight months of marriage range from $4 \%$ to $10 \%$, rates generally equal or below the non-Amish population. Out of wedlock conceptions frequently result in marriage (Cross and McKusick 1970; Donnermeyer and Cooksey 2004; Smith 1960; 1961). Rates of out of wedlock 
conceptions are lower for earlier cohorts and the New Order Amish (Donnermeyer and Cooksey 2004). Birth seasonality for one Amish settlement generally followed national norms until the 1990s when the historic spring trough for the national population was somewhat eliminated while it remained for the Amish, perhaps because of their non-use of A/C units (Greksa 2003). Another settlement had a higher instance of autumn births (Lucas, et al. 1991). Gender ratios of offspring fluctuate over time but tend to favor males more than the U.S. population (Cross and McKusick 1970; Smith 1960). Nevertheless, males have a higher mortality rate, so that the ratio is nearly 50/50 by young adulthood. During imbalanced periods, overrepresented genders increasingly marry across spatially separate communities (Smith 1960).

Variation in fertility is associated with several variables. Households involved in full time farming had higher fertility than those working in home businesses or as laborers (Dorsten 1999; Ericksen, et al. 1979; Wasao and Donnermeyer 1996), evident more in later years of marriage than early years (Markle and Pasco 1977). A positive association exists between an individual's childhood family size and adult marital fertility (Ericksen, et al. 1979). The ordained have more children than laity and conservative sub-affiliations more than progressive (Wasao and Donnermeyer 1996). In large settlements, progressive districts have lower fertility than conservative (Dorsten 1999).

\section{Infant Mortality}

The demographic transition theory associates natural fertility populations with high mortality. In the Amish case, high birth rates have persisted while infant mortality has dropped parallel to the United States (Acheson 1994; Khoury, et al. 1987c). Compared to non-Amish, Amish pregnancy complications occur as frequently (Lucas, et al. 1991) or less frequently (Acheson 1994; Smith 1960). One of seven Amish households in an Ohioan settlement reported a fetal, infant, or child death (Acheson 1994) and only a minority of households in a Pennsylvania settlement reported no problems with still births, infant deaths, or pregnancy complications, though the infant death rate for the first 12 months was only $2 \%$ to $3 \%$ (Dorsten 1994; Ericksen et al. 1979), well below national averages during the twentieth century. The overall instance of fatal complications may appear larger because of a higher number of conceptions and longer childbearing time (Acheson 1994; Resseguie 1974).

Factors contributing to the low rate of stillbirths and infant deaths include low drug and alcohol use, low instance of STDs, social support (Acheson 1994), good nutrition, and availability and us of modern medical services (Ericksen, et al. 1979; Hewner 1998; Smith 1958). Factors that predict higher rates of still births or infant deaths include higher birth orders in larger families (stronger effect in progressive districts), prior infant mortality, earlier cohorts (cohorts born in the late 1980s had only a 7\% increased chance of survival than those born in the 1920s), younger age of mother (the relation holds up until the oldest age group, which then has increased risk), conservative districts (Dorsten 1994), and higher inbreeding coefficients (Khoury, et al. 1987b). As a total percentage of all infant deaths and prenatal deaths, those 
attributable to inbreeding have increased over time and tend to be clustered in sibships (Khoury, et al. 1987c). Birth intervals did not predict infant mortality (Dorsten 1994; Ericksen, et al. 1979).

Amish households consult three resource domains for pregnancy care: professional health practitioners; alternative practitioners like folk medicine, mid-wives, and birthing centers; and popular Amish wisdom (Campanella, Korbin, and Acheson 1993). Amish shy from regular dependence on professional health offerings, as pregnancy is a common state for married adults and one that is status enhancing, not a medical condition, per se. Nevertheless, a majority of actual Amish births are in hospitals, some in Amish birthing centers, and a small percentage in the home (Campanella, et al. 1993). In one settlement, Amish had shorter labor duration and heavier birth weights than non-Amish neighbors (Lucas, et al. 1991).

\section{Conclusion}

The demographic study of the Amish has had an energetic history, witnessing more academic publications in this subarea than about any other subarea of Amish studies. While Amish demographic research has made the most of the tools available at the time, we now have the ability to do much more comprehensive, thorough studies thanks to advances in data entry technology. Inspired by the unfinished work of the late Benjamin McKune, the six-member Amish Population Research Group (APRG) formed in response to the prospect of creating quality demographic data about the Amish and has developed a three-step research program.

First, the APRG envisions utilizing contemporary programming tools and human resources to develop multiple databases of Amish populations based on Amish directories, which in recent years have both proliferated and improved in quality.

Second, the APRG seeks to use these databases as a platform from which to revisit previous Amish demographic studies and update their findings in order to track population trends, such as birth and marriage patterns, among others.

Third, the APRG sees the Amish as an opportunity to interrogate broader demographic theory, especially as a notable case of a persistently high birth population in a now severalgenerations old low fertility country. We have received hints that the McKune dataset was intended to test theories in the sociology of religion; that is interesting, because our metaanalysis suggests that past studies using Amish population data have been more descriptive than theoretical, with few exceptions (e.g. Bailey and Collins 2011 or Wasao and Donnermeyer 1996).

In both sheer volume of data and application of the data to demographic theory, we anticipate a new surge of interest in the Amish case for its fascinating population dynamics and extend an invitation to demographers, medical researchers, and others to enter into collaborations with APRG. 


\section{Endnotes}

${ }^{1}$ Contact information: Corey Colyer, Corey.Colyer@mail.wvu.edu — Cory Anderson, Dept. of Society \& Env., Truman State University, 100 E. Normal Ave., Kirksville, MO 63501; 660-7854032; dranderson@beachyam.org

${ }^{2}$ The Association of Religion Data Archive (http://thearda.com)

${ }^{3}$ Microdata is information on individual units of analysis rather than tabulated aggregates. For instance, the U.S. Census Bureau's "Summary Files” present tables of totals. The Bureau's PUMS (Public Use Microdata Sample) files, however, contain the measurement data from the original census survey instrument with certain information removed to protect the anonymity of the respondent. Here, we point to the relative absence of usable microdata for Amish populations.

${ }^{4}$ Information about Mr. McKune and the data set were taken from the Association of Religion Data Archives webpage for the Census of the Amish in Holmes County and the Surrounding Areas (http://www.thearda.com/Archive/Files/Descriptions/AMISH.asp).

${ }^{5}$ Hostetler (1980[1963]) reports higher numbers that decline during the first decades of the century, but nevertheless are above $3 \%$.

${ }^{6}$ Lucas, et al. (1991) reported Amish in one moderately sized settlement tend to have first births later than the local rural population, though the latter had a much wider distribution of ages at first birth.

${ }^{7}$ http://groups.etown.edu/amishstudies/statistics/amish-population-profile-2016

${ }^{8}$ Students who receive a substantial scholarship from the university must work several hours a week. Employees of the university can post job listings on an internal website and students can apply for them.

\section{References}

Acheson, Louise. 1994. "Perinatal, Infant, and Child Death Rates among the Old Order Amish.” American Journal of Pepidemiology 139(2):173-83. https://doi.org/10.1093/oxfordjournals.aje.a116979

Adkins, Tabetha. 2011. "Researching the 'Un-Digital' Amish Community: Methodological and Ethical Reconsiderations for Human Subjects Research.” Community Literacy Journal 6(1):39-53. https://doi.org/10.1353/clj.2012.0014

Agarwala, Richa, Leslie Biesecker, Katherine Hopkins, Clair Francomano, and Alejandro Schäffer. 1998. "Software for Constructing and Verifying Pedigrees within Large 
Genealogies and an Application to the Old Order Amish of Lancaster County." Genome Research 8(3):211-21. https://doi.org/10.1101/gr.8.3.211

Agarwala, Richa, Leslie Biesecker, and Alejandro Schäffer. 2003. “Anabaptist Genealogy Database.” American Journal of Medical Genetics Part C: Seminars in Medical Genetics 121C(1):32-37. https://doi.org/10.1002/ajmg.c.20004

Anderson, Cory. 2016. "Religious Seekers' Attraction to the Plain Mennonites and Amish.” Review of Religious Research 58(1):125-47. https://doi.org/10.1007/s13644-015-0222-5

Armer, Jane, and M. Elise Radina. 2006. "Definition of Health and Health Promotion Behaviors among Midwestern Amish Families.” Journal of Multicultural Nursing \& Health 12(3):44-53.

Bailey, Martha , and William Collins. 2011. "Did Improvements in Household Technology Cause the Baby Boom? Evidence from Electrification, Appliance Diffusion, and the Amish.” American Economic Journal: Macroeconomics 3 3(2):189-217. https://doi.org/10.1257/mac.3.2.189

Burdge, Edsel. 2016. “Amish Demographics 2016.” Presentation at the Continuity and Change: 50 Years of Amish Society conference. Elizabethtown College, Elizabethtown, PA.

Campanella, Karla, Jill Korbin, and Louise Acheson. 1993. "Pregnancy and Childbirth among the Amish.” Social Science \& Medicine 36(3):333-42. https://doi.org/10.1016/02779536(93)90017-X

Cross, Harold 1976. "Population Studies and the Old Order Amish.” Nature 262(5563):17-20. https://doi.org/10.1038/262017a0

Cross, Harold, and Victor McKusick. 1970. “Amish Demography.” Social Biology 17(2):83101. https://doi.org/10.1080/19485565.1970.9987850

Cross, John. 2003. “Amish Surnames, Settlement Patterns, and Migration.” Names 51(3\&4):193-214. https://doi.org/10.1179/nam.2003.51.3-4.193

Donnermeyer, Joseph. 2015. “Doubling Time and Population Increase of the Amish.” Journal of Amish and Plain Anabaptist Studies 3(1):94-109.

Donnermeyer, Joseph, and Elizabeth Cooksey. 2004. “The Demographic Foundations of Amish Society / Blessings from God: Fertility Patterns among the Amish.” Presentation at the Annual Meeting of the Rural Sociological Society and the Annual Meeting of the American Sociological Association. San Francisco, CA.

Donnermeyer, Joseph, and Cory Anderson. 2015. “A Mid-Decade Update on Amish Settlement Growth.” Journal of Amish and Plain Anabaptist Studies 3(2):222-35.

Donnermeyer, Joseph, Cory Anderson, and Elizabeth Cooksey. 2013. "The Amish Population: County Estimates and Settlement Patterns.” Journal of Amish and Plain Anabaptist Studies 1(1):72-109. 
Donnermeyer, Joseph, and Elizabeth Cooksey. 2010. "On the Recent Growth of New Amish Settlements.” Mennonite Quarterly Review 84(2):181-206.

Dorsten, Linda. 1994. "Direct and Indirect Effects on Infant Mortality in a High-Fertility US Population.” Population Research and Policy Review 13(1):31-48. https://doi.org/10.1007/BF01074320

—. 1999. "Fertility Decline in a US Population Favoring Large Families: A Hazard-Model Analysis of the Effect of Sib Death on Amish Fertility.” Population Research and Policy Review 18:323-38. https://doi.org/10.1023/A:1006115313141

Dorsten, Linda Eberst, Lawrence Hotchkiss, and Terri King. 1996. "Consanguineous Marriage and Early Childhood Mortality in an Amish Settlement.” Sociological Focus 29(2):179-85. https://doi.org/10.1080/00380237.1996.10570639

Dorsten, Linda, Lawrence Hotchkiss, and Terri King. 1999. “The Effect of Inbreeding on Early Childhood Mortality: Twelve Generations of an Amish Settlement.” Demography 36(2):263-71. https://doi.org/10.2307/2648113

Enninger, Werner, and Karl-Heinz Wandt. 1982. "Pennsylvania German in the Context of an Old Order Amish Settlement: The Structural Instability of a Functionally Stable Variety.” Yearbook of German-American Studies 1982 17:123-43.

—. 1983. "Participant Observation: Methodological, Psychological, and Ethical Problems Experienced in a Language Contact Study.” Pp. 31-40 in Gegenwärtige Tendenzen in der Kontaktlinguistik, edited by P.H. Nelde. Bonn: Dummler.

Ericksen, Julia , Eugene Ericksen, John Hostetler, and Gertrude Enders Huntington. 1979. "Fertility Patterns and Trends among the Old Order Amish.” Population Studies 33(2):25576. https://doi.org/10.1080/00324728.1979.10410441

Espenshade, Thomas 1971. “A New Method for Estimating the Level of Natural Fertility in Populations Practicing Birth Control.” Demography 8(4):525-36. https://doi.org/10.2307/2060688

Finn, Julianna. 1995. "Leninger's Model for Discoveries at The Farm and Midwifery Services to the Amish.” Journal of Transcultural Nursing 7(1):28-35. https://doi.org/10.1177/104365969500700105

Friesen, Bruce, and John Friesen. 1996. Perceptions of the Amish Way. Dubuque, IA: Kendall/Hunt Publishing Company.

Grammich, Clifford, Kirk Hadaway, Richard Houseal, Dale Jones, Alexei Krindatch, Richie Stanley, and Richard Taylor. 2012. 2010 U.S. Religion Census: Religious Congregations and Membership Survey. Kansas City, MO: Association of Statisticians of American Religious Bodies. 
Greksa, Lawrence 2002. "Population Growth and Fertility Patterns in an Old Order Amish Settlement.” Annals of Human Biology 29(2):192-201. https://doi.org/10.1080/03014460110075684

—. 2003. "Birth Seasonality in the Old Order Amish.” Journal of Biosocial Science 36:299315.

Hewner, Sharon 1997. "Biocultural Approaches to Health and Mortality in an Old Order Amish Community.” Collegium Anthropologicum 21(1):67-82.

—. 1998. "Fertility, Migration, and Mortality in an Old Order Amish Community.” American Journal of Human Biology 10(4):619-28.

Hostetler, John. 1980[1963]. Amish Society. Baltimore, MD: Johns Hopkins University Press.

Hostetler, John 1963. Amish Society. Baltimore, MD: Johns Hopkins University Press.

—. 1984. "Silence and Survival Strategies among the New and Old Order Amish.” Pp. 81-91 in Internal and External Perspectives on Amish and Mennonite Life 1, edited by Werner Enninger. Essen, Germany: Unipress.

Hostetler, John, Julia Ericksen, Eugene Ericksen, and Gertrude Enders Huntington. 1977. “Fertility Patterns in an American Isolate Subculture.” NICHD, number HD-08137-01A1.

Hurd, James. 1985. “Kissing Cousins: Frequencies of Cousin Types in 'Nebraska' Amish Marriages.” Social Biology 32(1-2):82-89. https://doi.org/10.1080/19485565.1985.9988594

Hurd, James 1997. "Marriage Practices among the 'Nebraska’ Amish of Mifflin County.” Pennsylvania Mennonite Heritage (April):20-24.

Hurst, Charles, and David McConnell. 2010. An Amish Paradox: Diversity and Change in the World's Largest Amish Community Baltimore, MD: Johns Hopkins University Press.

Jolly, Natalie. 2014. "In This World but Not of It: Midwives, Amish, and the Politics of Power.” Sociological Research Online 19(2). https://doi.org/10.5153/sro.3294

Khoury, Muin, Bernice Cohen, Earl Diamond, Gary Chase, and Victor McKusick. 1987a. "Inbreeding and Prereproductive Mortality in the Old Order Amish I: Genealogic Epidemoiology of Inbreeding.” American Journal of Epidemiology 125(3):453-61. https://doi.org/10.1093/oxfordjournals.aje.a114551

—. 1987b. "Inbreeding and Prereproductive Mortality in the Old Order Amish III: Direct and Indirect Effects of Inbreeding.” American Journal of Epidemiology 125(3):473-83. https://doi.org/10.1093/oxfordjournals.aje.a114553

Khoury, Muin, Bernice Cohen, Carol Newill, Wilma Bias, and Victor McKusick. 1987c. "Inbreeding and Prereproductive Mortality in the Old Order Amish II: Genealogic Epidemoiology of Prereproductive Mortality.” American Journal of Epidemiology 125(3):462-72. https://doi.org/10.1093/oxfordjournals.aje.a114552 
Kollmorgen, Walter 1943. "The Agricultural Stability of the Old Order Amish and Old Order Mennonites of Lancaster County, Pennsylvania.” American Journal of Sociology 49(3):23341. https://doi.org/10.1086/219372

Kraybill, Donald. 2001. The Riddle of Amish Culture. Baltimore, MD: John Hopkins University Press.

Lee, Woei-Jyh, Toni Pollin, Jeffrey O'Connell, Richa Agarwala, and Alejandro Schäffer. 2010. "PedHunter 2.0 and Its Usage to Characterize the Founder Structure of the Old Order Amish of Lancaster County.” BMC Medical Genetics 11:68-68. https://doi.org/10.1186/1471-2350$11-68$

Lehman, Elton. 1994. "Providing Healthcare in Amish Country.” Multicultural Education Journal 12(2):11-15.

Lucas, Cheryl , Robert O'Shea, Maria Zielezny, Jo Freudenheim, and James Wild. 1991. "Rural Medicine and the Closed Society: Pregnancy Outcomes among Amish and NonAmish Women.” New York State Journal of Medicine 91:49-52.

Markle, Gerald , and Sharon Pasco. 1977. "Family Limitation among the Old Order Amish.” Population Studies 31(2):267-80. https://doi.org/10.2307/2173918

McKusick, Victor (Ed.). 1978. Medical Genetic Studies of the Amish: Selected Papers. Baltimore, MD: Johns Hopkins University Press.

McKusick, Victor , John Hostetler, and Janice Egeland. 1964. "Genetic Studies of the Amish.” Bulletin of the John Hopkins Hospital (115):203-22.

Resseguie, Laurence. 1974. "Pregnancy Wastage and Age of Mother among the Amish.” Human Biology 46(4):633-39.

Savells, Jerry, and Thomas Foster. 1987. "The Challenges and Limitations of Conducting Research among the Old Order Amish.” Explorations in Ethnic Studies 10(1):25-39.

Schwieder, Elmer, and Dorothy Schwieder. 1975. A Peculiar People: Iowa's Old Order Amish. Ames, IA: Iowa State University Press.

Scott, Stephen. 2007. "New Comers: English Converts to the Amish.” Presented at The Amish in America: New Identities \& Diversities conference. Elizabethtown, PA.

Smith, Elmer Lewis. 1956. “A Study of Acculturation in an Amish Community.” Dissertation in Sociology. Syracuse, NY: Syracuse University.

- 1958. The Amish People: Seventeenth-Century Tradition in Modern America. New York: Exposition Press.

—. 1960. "Studies in Amish Demography.” Harrisonburg, VA: Research Council of Eastern Mennonite College. 
—. 1961. The Amish Today: An Analysis of Their Beliefs, Behavior, and Contemporary Problems: Pennsylvania German Folklore Society.

Stevenson, J.C., P.M. Everson, and M.H. Crawford. 1989. "Changes in Completed Family Size and Reproductive Span in Anabaptist Populations.” Human Biology 61(1):99-115.

Tell, Shoshana. 2012. "Medical Genetic Research on the Amish: From Genetic Tourism to Community Health Centers.” Einstein Journal of Biology and Medicine:18-24.

Wasao, Samson , and Joseph Donnermeyer. 1996. "An Analysis of Factors Related to Parity among the Amish in Northeast Ohio.” Population Studies 50:235-46.

https://doi.org/10.1080/0032472031000149326

Webb, Eugene, Donald Campbell, Richard Schwartz, and Lee Sechrest. 1966. Unobtrusive Measures: Nonreactive Research in the Social Sciences. Chicago, IL: Rand McNally.

Wenger, Anna Frances , and Marion Wenger. 1998. “The Amish.” Pp. 75-105 in Transcultural Health Care: A Culturally Competent Approach, edited by L.D. Purnell and B.J. Paulanka. Philadelphia, PA: FA Davis Company.

Wood, James, Darryl Holman, Anatoli Yashin, Raymond Peterson, Maxine Weinstein, and Ming-Cheng Chang. 1994. "A Multistate Model of Fecundability and Sterility.” Demography 31(3):403-26. https://doi.org/10.2307/2061750

Yost, Berwood, Christina Abbot, Jennifer Harding, and Angela Knittle. 2005. "Among the Amish: Interviewing Unique Populations on Sensitive Topics.” Public Opinion Pros 2005 (June). 